\title{
A putative multicopper protein secreted by an atypical type II secretion system involved in the reduction of insoluble electron acceptors in Geobacter sulfurreducens
}

Correspondence
Tünde Mester
tmester@microbio.umass.edu

Received 23 January 2006

Revised 19 April 2006

Accepted 4 May 2006

\author{
Teena Mehta, Susan E. Childers, † Richard Glaven, Derek R. Lovley \\ and Tünde Mester
}

Department of Microbiology, Morrill IV North, University of Massachusetts, Amherst, MA 01003, USA

\begin{abstract}
Extracellular electron transfer onto Fe(III) oxides in Geobacter sulfurreducens is considered to require proteins that must be exported to the outer surface of the cell. In order to investigate this, the putative gene for OxpG, the pseudopilin involved in a type II general secretion pathway of Gram-negative bacteria, was deleted. The mutant was unable to grow with insoluble Fe(III) oxide as the electron acceptor. Growth on soluble Fe(III) was not affected. An analysis of proteins that accumulated in the periplasm of the $\operatorname{xpG}$ mutant, but not in the wild-type, led to the identification of a secreted protein, $\mathrm{OmpB}$. OmpB is predicted to be a multicopper protein, with highest homology to the manganese oxidase, MofA, from Leptothrix discophora. OmpB contains a potential $\mathrm{Fe}(\mathrm{III})$-binding site and a fibronectin type III domain, suggesting a possible role for this protein in accessing $\mathrm{Fe}$ (III) oxides. OmpB was localized to the membrane fraction of G. sulfurreducens and in the supernatant of growing cultures, consistent with the type II secretion system exporting OmpB. A mutant in which ompB was deleted had the same phenotype as the oxpG mutant, suggesting that the failure to export OmpB was responsible for the inability of the oxpG-deficient mutant to reduce $\mathrm{Fe}$ (III) oxide. This is the first report that proposes a role for a multicopper oxidase-like protein in an anaerobic organism. These results further emphasize the importance of outer-membrane proteins in Fe(III) oxide reduction and suggest that outer-membrane proteins other than c-type cytochromes are required for Fe(III) oxide reduction in Geobacter species.
\end{abstract}

\section{INTRODUCTION}

Microbial oxidation of organic matter coupled to the reduction of $\mathrm{Fe}(\mathrm{III})$ oxides is an important process in the carbon cycle of a variety of sedimentary environments (Lovley, 2000). Micro-organisms growing via Fe(III) reduction in subsurface environments can simultaneously reduce toxic metals such as $\mathrm{U}(\mathrm{VI}), \mathrm{Tc}(\mathrm{VII})$, Co (III) and $\mathrm{V}(\mathrm{V})$, which may be a useful strategy for the bioremediation of metal-contaminated subsurface environments (Anderson \& Lovley, 2002; Anderson et al., 2003; Caccavo et al., 1994; Finneran et al., 2002; Holmes et al., 2002; Lloyd \& Lovley, 2001; Ortiz-Bernad et al., 2004). Furthermore, microbiological and geological evidence suggests that $\mathrm{Fe}(\mathrm{III})$ reduction

tPresent address: Department of Geological Sciences, University of Idaho, Moscow, ID 83844 - 3022, USA.

Abbreviations: MALDI-MS, matrix-assisted-laser-desorption/ionization time-of-flight mass spectrometry; NTA, nitrilotriacetic acid; PSD, postsource decay.

Four supplementary figures are available with the online version of this paper. was an important form of respiration on early Earth (Lovley et al., 2004; Tor et al., 2004; Vargas et al., 1998; Walker, 1987).

Molecular analysis has demonstrated that, with the exception of highly saline environments (Nevin et al., 2003), Geobacteraceae are the predominant Fe(III)-reducing microorganisms in a diversity of sedimentary environments in which $\mathrm{Fe}(\mathrm{III})$ reduction is an important process (Anderson et al., 2003; Holmes et al., 2002; North et al., 2004; Röling et al., 2001; Rooney-Varga et al., 1999; SnoeyenbosWest et al., 2000; Stein et al., 2001). The primary form of $\mathrm{Fe}(\mathrm{III})$ in such environments is insoluble $\mathrm{Fe}(\mathrm{III})$ oxide (Lovley, 1991; Nevin \& Lovley, 2002). The available evidence suggests that Geobacter species must directly contact $\mathrm{Fe}$ (III) oxides in order to reduce them (Childers et al., 2002; Lovley et al., 2004; Nevin \& Lovley, 2000). Thus, electron transfer to $\mathrm{Fe}(\mathrm{III})$ oxides is expected to take place at or near the outer cell surface (Lovley et al., 2004).

Most studies on electron transfer to Fe(III) in Geobacter and other dissimilatory $\mathrm{Fe}(\mathrm{III})$ reducers, such as Shewanella 
species, have focused on the role of $c$-type cytochromes (Lovley et al., 2004; Richardson 2000). The genome of G. sulfurreducens reveals an exceptional number of putative $c$-type cytochromes (Methe et al., 2003), many of which are predicted to be membrane-bound, and some of which are required for Fe(III) reduction (Leang et al., 2003; Lloyd et al., 2003; Reguera et al., 2005; Mehta et al., 2005).

However, proteins aside from cytochromes may also be important in $\mathrm{Fe}(\mathrm{III})$ oxide reduction. For example, pili are expressed during growth on $\mathrm{Fe}(\mathrm{III})$ oxide, but not soluble $\mathrm{Fe}$ (III) citrate, and a pilus-deficient mutant could not reduce $\mathrm{Fe}(\mathrm{III})$ oxides (Childers et al., 2002; Reguera et al., 2005). Studies on the pili of G. sulfurreducens revealed the presence of a homologue for pilA, the gene for the structural pilin protein. A phylogenetic analysis placed the protein among the bacterial pseudopilins of type II secretion systems (Reguera et al., 2005).

In several Gram-negative bacteria, type II secretion systems are responsible for the translocation of proteins into or through the outer membrane (Arrieta et al., 2004; Pugsley, 1993a; Sandkvist, 2001a). Classical type II general secretion pathways (GSPs), such as the pullulanase system ( $p u l$ ) of Klebsiella oxytoca (d'Enfert et al., 1987), consist of 12-15 interacting proteins whose genes and genetic arrangement are well conserved among bacteria (Filloux, 1999; Pugsley, 1993b; Sandkvist, 2001b). Pseudopilins are proposed to form a pilus-like periplasmic structure that assists in the secretion of proteins either by providing a channel to the outside of the cell that proteins can pass through or by acting as a piston to push out proteins (Nunn, 1999; Vignon et al., 2003).

Here we report that the pseudopilin gene of G. sulfurreducens is required for reduction of insoluble $\mathrm{Fe}(\mathrm{III})$ and $\mathrm{Mn}(\mathrm{IV})$ oxide, but not the reduction of soluble Fe(III) in G. sulfurreducens. One of the proteins secreted by this putative type II secretion system is OmpB, a putative multicopper, outermembrane protein that is specifically required for the reduction of $\mathrm{Fe}(\mathrm{III})$ oxide, but not soluble $\mathrm{Fe}(\mathrm{III})$.

\section{METHODS}

Bacterial strains and culture conditions. Escherichia coli strain DH5 $\alpha$ [supE44A lacU169 ( $\phi 80$ lacZAM15) hsdR17 recA1 endA1 gyrA96 thi-1 relA1] was used for DNA manipulations (Hanahan, 1983; Woodcock et al., 1989). Targeted gene disruption experiments were performed on Geobacter sulfurreducens strain DL1 to produce oxpG::kan and ompB::spec strains). G. sulfurreducens strain PCA (ATCC 51573) (Caccavo et al., 1994) was obtained from our laboratory culture collection. Cells were cultured with acetate as the electron donor and either fumarate $(40 \mathrm{mM}), \mathrm{Fe}(\mathrm{III})$ citrate $(50 \mathrm{mM})$ or poorly crystalline $\mathrm{Fe}(\mathrm{III})$ oxide $(100 \mathrm{mM})$ as the electron acceptor as previously described (Coppi et al., 2001). Nitrilotriacetic acid (NTA) was added at a concentration of $4 \mathrm{mM}$ or $1 \mathrm{mM}$. Kanamycin, streptomycin and spectinomycin were added at final concentrations of $200 \mu \mathrm{g} \mathrm{ml}^{-1}$ when required.

DNA manipulations and RT-PCR conditions for RNA expression analysis. Genomic DNA was extracted with the Master Pure
Complete DNA and RNA purification kit (Epicenter Technologies). Plasmid purification was carried out with the Mini Plasmid purification kit (Qiagen). Total RNA was purified from mid-exponentialphase cultures with RNeasy Mini kits (Qiagen) followed by treatment with RNase-free DNase (Ambion). Reverse transcription was performed with the Omniscript RT kit (Qiagen) according to the manufacturer's instructions. Total RNA $(1 \mu \mathrm{g})$ served as template for cDNA synthesis and random hexamers were used as primers. The resultant cDNA was amplified with primers: OxpGF (5'-CTGCAGGAAAACCTCTACACC-3') and OxpGR (5'-GAACTGACAAGGTCTGAGCCG-3') for the $\exp G$ gene.

Construction of an $\operatorname{expG}$ deletion mutant. In order to create an oxpG mutant, recombinant PCR (Murphy et al., 2000) was used to construct a linear DNA fragment containing the first $0.038 \mathrm{~kb}$ of the $\operatorname{oxp} G$ gene preceded by upstream sequence and followed by a kanamycin resistance cassette, the last $0 \cdot 1 \mathrm{~kb}$ of the hyaB gene, and $0 \cdot 1 \mathrm{~kb}$ of downstream sequence. In creation of a $\operatorname{xxp} G$ deletion mutant, primers Gspl (5'-GCCTCTGGATATAATTCCTTAC-3') and Gsp2 (5'-GGGTAAACCCCTTGCGGTTACG-3') were used to amplify the sequence upstream of $\operatorname{oxp} G(576 \mathrm{bp} ;-572$ to +38$)$; primers Gsp3 (5'-GGGCTCGTGAGGCTGTCCTGCAGG-3') and Gsp4 (5'-CGTCGTTAAGGGCAGCCATGTCGC-3') were used to amplify the sequence downstream of $\operatorname{oxp} G(410 \mathrm{bp}$; from +115 to $113 \mathrm{bp}$ downstream from the stop site). A kanamycin resistance cassette was amplified from pBBR1MCS-2 (Kovach et al., 1995) with primers KanF (5'-CGTAACCGCAAGGGGTTTACCCACCTGGGATGAATGTCAGCTA-3') and KanR (5'-GCAGGACAGCCTCACGAGCCCAAGCCCAACCTTTCATAGA-3'). Recombinant PCR was performed using primers Gsp1 and Gsp4. Electroporation, mutant isolation and genotype confirmation using Southern hybridization were performed as described by Coppi et al. (2001). Southern hybridization with $G$. sulfurreducens genomic DNA was performed according to Sambrook et al. (1989). Probes were labelled with $\left[\alpha-{ }^{32} \mathrm{P}\right] \mathrm{dCTP}$ (Perkin Elmer) with the Multiprime DNA labelling system (Amersham Pharmacia Biotech). One of the correct genotype mutants, designated DLTM2, was chosen as the representative strain.

Construction of an ompB deletion mutant. The $\operatorname{smp} B$-deficient strain was created essentially the same way as for the $\exp G$ mutant strain. Primers rgR1 (5'-GCTAGAATTCGGCGACGCGCTCCGAG-3') and $\operatorname{rgR} 2$ (5'-GCATGGATCCAGAACGGTTCCTGC-3') were used to amplify a $0.5 \mathrm{~kb}$ fragment located upstream of $o m p B$. Primers rgR3 (5'-CAGGGTGTCGACGAATTTCCGCAT-3') and rgR4 (5' GCATAAGCTTGTAAGCCGATTTGATG- $3^{\prime}$ ) were used to amplify a $0.5 \mathrm{~kb}$ fragment located downstream of $o m p B$. The aadA spectinomycin resistance cassette was cloned from pSJS985 (Sandler \& Clark, 1994) using primers RGspcRV1 (5'-CGATGATATCGCACAGGATGACGCCTAAC-3') and RGspcRV2 (5'-GCGATGATATCGAAGCGGCGTCGGCTTG-3'). The primers rgR1 and rgR4 were used to amplify the $1.9 \mathrm{~kb}$ fragment and used to perform single-step gene replacement according to the method of Leang et al. (2003). The mutation again was confirmed by Southern blot hybridization.

Expression of the $\operatorname{oxp} G$ and $\mathrm{ompB}$ genes in trans. The mutant $\Delta g s p:$ :kan was complemented using the expression vector pCDS as described previously (Leang et al., 2003). The primers used to amplify $\exp G$ were: forward primer, $5^{\prime}$-CCCGGAATTCCCCGAAGTGGGTGAGCC-3'; and reverse primer, 5'-CCGGGATCCCGCGCTGGTATGACATGG-3' (with EcoRI and BamHI restriction sites underlined). The $\exp G$ coding sequence was digested with $E c o$ RI and $B a m H I$ and inserted into the EcoRI and BamHI sites of the expression vector pCDS to generate pCDS-oxpG. The $\operatorname{oxp} G$ gene was sequenced to screen for PCR artefacts. The oxpG deletion mutant was electroporated with pCDS-oxpG. Streptomycin was used as the selection marker to screen for the insert. The strain was designated DLTM2C. Successful transformants were screened for the insert in the correct orientation. 
When $о m p B$ was expressed in trans, an expression vector derived from pCM66 (Marx \& Lidstrom, 2001) was constructed. Primers rgG1 (5'-CCGAGACATGTCAACAGCTGATTGCCCTTCAC-3') and rgG2 (5'-CCGAGGACGTCGCGAAAACTCTCAAGGATCTTAC-3') were used to amplify a $1.8 \mathrm{~kb}$ fragment from pCD342 (Dehio et al., 1998). The PCR product was digested with AflII/AatIII and ligated to the $5.9 \mathrm{~kb}$ AatII/AflIII fragment from pCM66 to create pRG2. Primers rgR5 (5'-GCGATGAATTCTTACTGGATCGTCAGGTTGTTGAC-3') and rgR6 (5'-GCGATGAATTCCACAAAGGAGACATTTGATC- $3^{\prime}$ ) were used to amplify the $O m p B$ gene and the native ribosome-binding site. The $4 \mathrm{~kb}$ PCR product was digested with EcoRI and HindIII and ligated with EcoRI/HindIII pRG2 to create pRG2ompB. Further procedures were identical to those of $\exp G$ expression.

Analytical techniques. Cell suspension experiments were carried out as previously described (Leang et al., 2003). Fe(III) reduction was monitored by measuring the accumulation of $\mathrm{HCl}$-extractable $\mathrm{Fe}(\mathrm{II})$ with ferrozine as previously described (Lovley \& Phillips, 1986). Growth on fumarate was monitored spectrophotometrically by measuring the turbidity at $600 \mathrm{~nm}$. Cell densities of other cultures were determined by acridine orange staining and epifluorescence microscopy (Lovley \& Phillips, 1988).

Isolation of periplasmic proteins. Cells grown with insoluble $\mathrm{Fe}$ (III) oxide as terminal electron acceptor supplemented with $4 \mathrm{mM}$ NTA were grown to exponential phase. Cells were harvested after dissolving the insoluble $\mathrm{Fe}(\mathrm{III})$ oxide using oxalate solution ( $28 \mathrm{~g}$ ammonium oxalate $1^{-1}$ and $15 \mathrm{~g}$ oxalic acid $\mathrm{l}^{-1}$ ). The cells were pelleted by centrifugation at $3000 \mathrm{~g}$ for $20 \mathrm{~min}$, washed in PBS buffer and centrifugation was repeated. Cell pellets were resuspended in $25 \mathrm{mM}$ HEPES (pH 7.5), $0.5 \mathrm{mM} \mathrm{MgCl}_{2}$ and $20 \%$ sucrose containing protease inhibitor. Cells were stirred for $20 \mathrm{~min}$ on ice. EDTA (pH 8.0) was added to a final concentration of $10 \mathrm{mM}$ and the suspension was stirred on ice for 5-10 min. Lysozyme was added at a final concentration of $0.5 \mathrm{mg} \mathrm{ml}^{-1}$ and stirring continued for another $30 \mathrm{~min}$ at room temperature to generate spheroplasts. The spheroplasts were pelleted by centrifugation at $5000 \mathrm{~g}$ at $4{ }^{\circ} \mathrm{C}$ for $15 \mathrm{~min}$. The outer-membrane fraction was removed from this preparation by centrifugation at $50000 \mathrm{~g}$ at $4{ }^{\circ} \mathrm{C}$ for $1 \mathrm{~h}$. The supernatant was used as the periplasmic fraction.

Identification of OmpB. The protein was excised from the SDS gel and digested with trypsin according Gharahdaghi et al. (1999). Digests were concentrated using ZipTip C18 pipette tips (Millipore) according to the recommended protocol with the exception of $1 \%$ formic acid instead of trifluoroacetic acid. MALDI-MS (matrixassisted-laser-desorption/ionization time-of-flight) and PSD (postsource decay) data were obtained on a Kratos Axima CFR (Kratos Analytical).

Gel electrophoresis and Western blot analysis. Samples were electrophoresed on $10 \%$ SDS polyacrylamide gels and visualized via Coomassie staining, with SeeBluePlus prestained proteins (Invitrogen) or subjected to Western analysis by transferring the proteins to Immuno blot PVDF membrane (Bio-Rad). The membrane was probed with a polyclonal antibody raised against a peptide of $\mathrm{OmpB}$ (KPDKTPIGPGDTPDC) (Sigma Genosys). Polyclonal alkaline phosphatase conjugated anti-rabbit antibody (Sigma) was used as secondary antibody, OmpB was visualized by SigmaFast 5-bromo-4chloro-3-indolyl phosphatase/nitro blue tetrazolium tablets (Sigma).

\section{RESULTS}

\section{Identification and expression of $\operatorname{expG}$}

An ORF (GI-39996875) containing an N-terminal signal sequence, 81 \% identical to the PilA gene of G. sulfurreducens, was identified in the G. sulfurreducens genome (Reguera et al., 2005). This gene was designated oxide reducing pathway protein $\mathrm{G}(\operatorname{oxp} G)$ because PSORT analysis (Nakai \& Horton, 1999) and FingerPRINTScan (http://www.bioinf. man.ac.uk/fingerPRINTScan/) suggested that this ORF is similar to the genes for a general secretion pathway protein $\mathrm{G}$ related to type II general secretion pathways of Gramnegative bacteria. $\exp G$ is not part of the classical type II secretion system, which has been described previously (Sandkvist, 2001b). The arrangement of the ORFs surrounding the putative G. sulfurreducens oxpG (see Supplementary Fig. S1, available with the online version of this paper) is like that around the gene $x \mathrm{~cm}$, part of a novel secretion system in Pseudomonas putida GB-1 that is required for secretion of a copper-containing manganese oxidase (De Vrind et al., 2003). The gene arrangement surrounding the G. sulfurreducens $\operatorname{oxp} G$ is also found in Geobacter metallireducens (http://www.jgi.doe.gov).

RT-PCR analysis revealed that $\operatorname{oxp} G$ was expressed under all culture conditions studied, which included growth with $\mathrm{Fe}$ (III) citrate, fumarate, or insoluble $\mathrm{Fe}(\mathrm{III})$ or $\mathrm{Mn}$ (IV) oxides as the electron acceptor (see Supplementary Fig. S2).

\section{Characterization of the oxpG deletion mutant}

In order to identify the potential role of OxpG in $\mathrm{Fe}(\mathrm{III})$ respiration, an $\exp G$ deletion mutant was constructed and was confirmed by Southern hybridization. Examination of the mutant by transmission electron microscopy demonstrated that it continued to produce pilin (data not shown).

The mutant reduced $\mathrm{Fe}(\mathrm{III})$ citrate (see Supplementary Fig. S3A) or fumarate (data not shown) as well as the wildtype. However, the $\operatorname{oxp} G$ deletion mutant was severely impaired in its ability to reduce insoluble Fe(III) (Fig. 1) and $\mathrm{Mn}(\mathrm{IV})$ oxides (data not shown). The mutant reduced $\mathrm{Fe}(\mathrm{III})$ in the $\mathrm{Fe}(\mathrm{III})$ oxide medium when the $\mathrm{Fe}(\mathrm{III})$ chelator NTA was added (Fig. 1). These results further suggested that the deletion of $\exp G$ specifically affected the secretion of proteins required for reduction of insoluble electron acceptors. When $\operatorname{oxp} G$ was expressed in the deletion mutant in trans, the capacity for $\mathrm{Fe}(\mathrm{III})$ oxide reduction was restored (Fig. 1).

\section{Identification of OmpB from the oxpG mutant}

Mutations in genes involved in type II secretion in other organisms result in accumulation of exoproteins within the periplasm (Pugsley, 1993a). Therefore, in order to identify proteins secreted by the OXP-like system in G. sulfurreducens, the periplasmic protein fractions of mutant and wild-type cells were compared (Fig. 2). A protein with an approximate molecular mass of $140 \mathrm{kDa}$ accumulated in the periplasm of the mutant cells (Fig. 2). The MALDI-MS analysis of this protein indicated that it was encoded by ORF GI-39996496 in the G. sulfurreducens genome (Methe et al., 2003). The protein was named outer-membrane protein B (OmpB). 

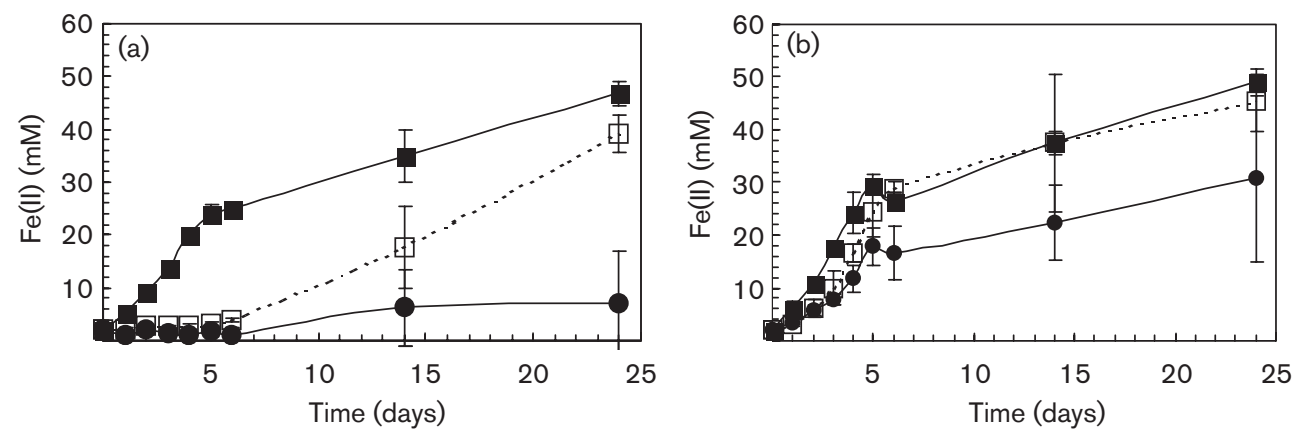

Fig. 1. Effect of $\operatorname{xppG}$ deletion on the reduction of insoluble Fe(III) oxide: time-course of Fe(III) reduction by the wild-type strain ( $\square)$, the oxpG mutant strain ( $\bullet$ ) and the oxpG mutant strain complemented with oxpG in trans ( $\square$ ) in the absence (a) and presence $(b)$ of $4 \mathrm{mM}$ NTA. The results are the means of triplicate incubations; error bars represent SD.

\section{Characterization and expression of OmpB}

The deduced amino acid sequence of OmpB indicates that this protein is a putative multicopper oxidase having the

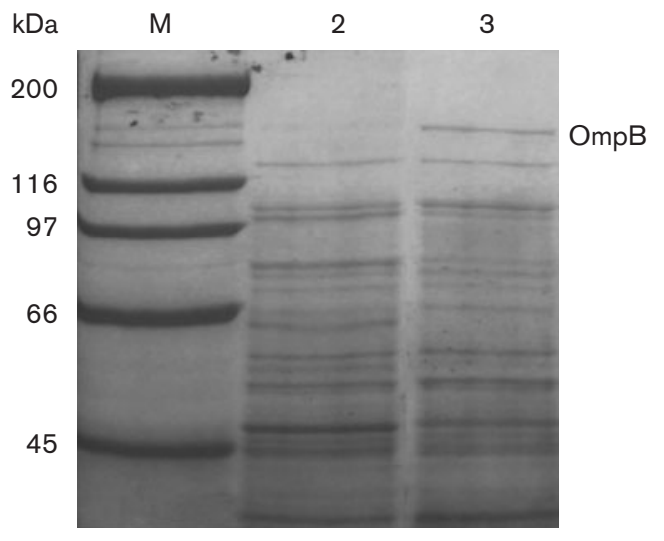

Fig. 2. Comparison of protein patterns in the periplasmic fractions of wild-type and oxpG mutant cells. Proteins from the periplasmic fraction were separated on a $7 \cdot 5 \%$ polyacrylamideSDS gel. OmpB was excised and sequenced by MALDI-MS with PSD analysis. Lanes: M, molecular mass markers; 2, wildtype; 3, oxpG mutant. highest similarity to a manganese oxidase (MofA) from Leptothrix discophora (see Supplementary Fig. S4). The sequence contains four deduced copper-binding sites, two near the amino terminus and two near the $\mathrm{C}$-terminus. This arrangement is typical of copper oxidases (Brouwers et al., 2000b). The protein consists of 1303 aa, with a calculated molecular mass of $139 \cdot 6 \mathrm{kDa}$, and a pI of $4 \cdot 47$. A 26 aa signal peptide was predicted, indicating the importance of the secretion pathway in the transport of this protein. The protein is predicted to be extracellular (PSORTB at http:// www.expasy.org). However, when the various cell fractions were run on a SDS-PAGE, OmpB was identified in both the membrane fraction and the extracellular fluid, but not in the soluble fraction of the cells (Fig. 3), suggesting that OmpB is cell-surface exposed. Western blot analysis also indicated that OmpB is expressed at the same levels during growth with soluble electron acceptors, or insoluble Fe(III) oxide or $\mathrm{Mn}$ (IV) oxide (Fig. 3).

\section{Effect of $\mathrm{ompB}$ mutation on growth with different electron acceptors}

A mutant in which $\operatorname{omp} B$ was deleted reduced $\mathrm{Fe}(\mathrm{III})$ citrate (see Supplementary Fig. S3B), and fumarate (data not shown) as well as the wild-type. The mutation did not affect the growth in either medium, as monitored by cell counting and optical density, respectively (data not shown). However,

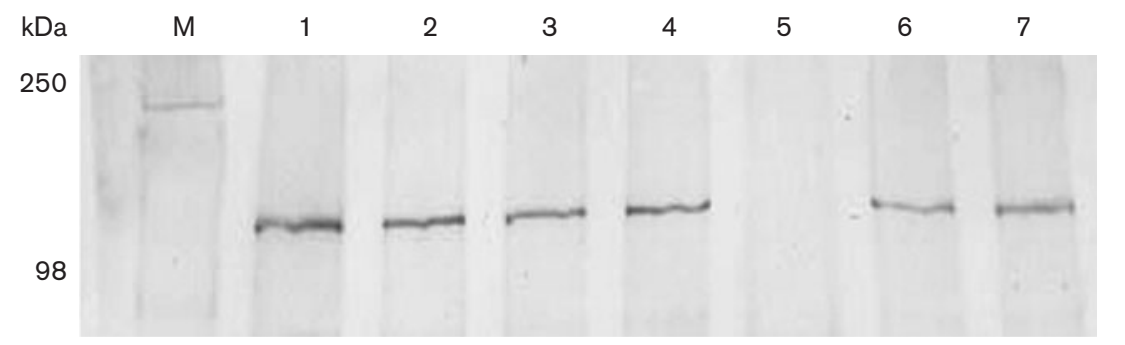

Fig. 3. Expression of OmpB under various culture conditions and in subcellular fractions. Western blot analysis was carried out with cell lysate from $\mathrm{Mn}(\mathrm{IV})$ oxide- (lane 1), Fe(III) oxide- (lane 2), Fe(III) citrate- (lane 3) and fumarate-containing (lane 4) cultures. The presence of OmpB was tested in the soluble fraction of cell lysate (lane 5), membrane fraction (lane 6) and extracellular supernatant of fumarate cultures (10-fold concentrated) (lane 7). M, molecular mass markers. Each lane was loaded with $5 \mu \mathrm{g}$ protein. 

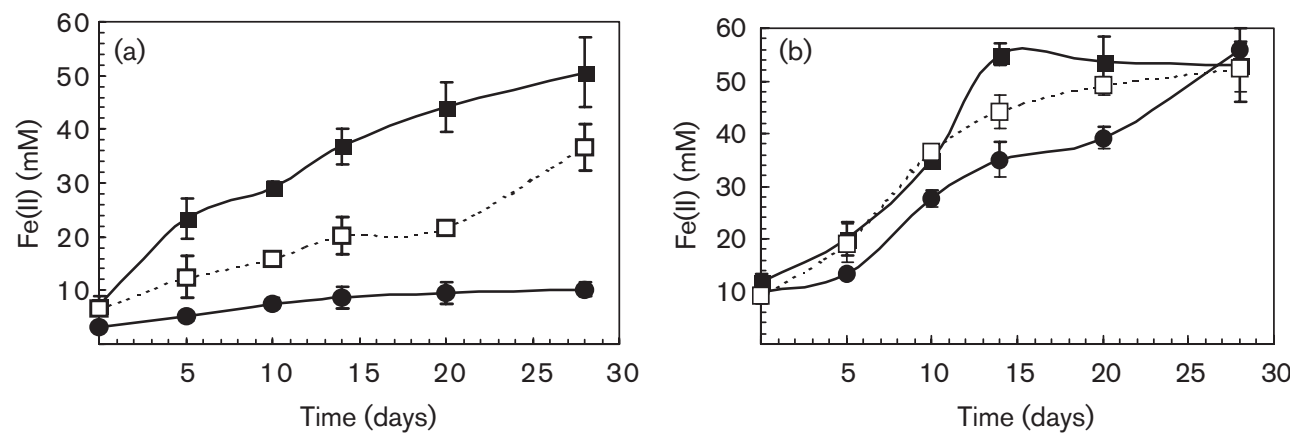

Fig. 4. Reduction of insoluble Fe(III) oxide (a) or Fe(III) oxide supplemented with $1 \mathrm{mM}$ NTA (b) by cultures of wild-type strain $(\boldsymbol{\square})$, ompB deletion mutant strain (๑), or ompB deletion mutant strain complemented with ompB in trans ( $\square)$. The results are the means of triplicate incubations; error bars represent SD.

the mutant poorly reduced insoluble Fe(III) oxide (Fig. 4a) and $\mathrm{Mn}(\mathrm{IV})$ (Fig. 5). When the chelator NTA was added to the cultures containing $\mathrm{Fe}(\mathrm{III})$ oxide, there was no significant difference between the mutant and the wild-type in the reduction of $\mathrm{Fe}(\mathrm{III})$ (Fig. $4 \mathrm{~b}$ ). When the mutant was complemented with ompB in trans, the reduction of $\mathrm{Fe}$ (III) oxide was restored, but the rate was somewhat slower than that of the wild-type (Fig. 4a). The complementation of ompB in trans also restored the reduction of $\mathrm{Mn}(\mathrm{IV})$ (Fig. 5).

\section{DISCUSSION}

The results demonstrate that a type II secretion system is required in G. sulfurreducens for the reduction of insoluble $\mathrm{Fe}(\mathrm{III})$ and $\mathrm{Mn}(\mathrm{IV})$ oxides and that this is related, at least in part, to the need to export a putative multicoppercontaining protein to the outer surface of the cell. As detailed below, these results further emphasize that reduction of insoluble $\mathrm{Fe}(\mathrm{III})$ oxides requires cell components not needed to reduce soluble, chelated $\mathrm{Fe}(\mathrm{III})$. This is an important distinction because most of the $\mathrm{Fe}(\mathrm{III})$ available for microbial reduction in soils and sediments is expected to be insoluble (Lovley, 1991; Nevin \& Lovley, 2002). Furthermore, the results demonstrate that, in addition to the $c$-type cytochromes that are widely regarded to be important outer-membrane proteins for electron transport and/or $\mathrm{Fe}(\mathrm{III})$ reduction, other proteins that are not cytochromes are also necessary for this process.

\section{Role of OxpG in Fe(III) oxide reduction}

The results suggest that the OxpG is involved in exporting $\mathrm{OmpB}$, and possibly other proteins, specifically required for the reduction of $\mathrm{Fe}(\mathrm{III})$ and $\mathrm{Mn}$ (IV) oxides. OxpG is most homologous to XcmT3, a type II pseudopilin from Pseudomonas putida strain GB-1 (De Vrind et al., 2003) and the genomic region flanking the $\exp G$ gene cluster also has similarity to the $x \mathrm{~cm} T 3$ gene cluster. Genetic studies have demonstrated that the XcmX secretion system in $P$. putida strain GB-1 is involved in the secretion of a manganeseoxidizing enzyme (De Vrind et al., 2003), which is also a multicopper oxidase (Brouwers et al., 1999).

A type II secretion system is also required for $\mathrm{Fe}(\mathrm{III})$ reduction in the dissimilatory $\mathrm{Fe}(\mathrm{III})$ reducer Shewanella putrefaciens (DiChristina et al., 2002). When ferE, the gspE homologue in the $S$. putrefaciens secretion system, was deleted, $\mathrm{Fe}(\mathrm{III})$ and $\mathrm{Mn}(\mathrm{IV})$ reduction were inhibited. However, there are some significant differences between the systems required for $\mathrm{Fe}(\mathrm{III})$ reduction in S. putrefaciens and G. sulfurreducens. For example, the secretion system required for $\mathrm{Fe}(\mathrm{III})$ reduction in S. putrefaciens is more closely related to the classical type II GSP systems of Gramnegative bacteria that are involved in translocating toxins and hydrolases (Sandkvist, 2001b). In fact, the gene arrangement in S. putrefaciens is identical to that of Vibrio cholerae (Sandkvist, 2001b). In contrast, the arrangement of the genes surrounding $\exp G$ in G. sulfurreducens is similar to that of the non-classical XcmX secretion system of $P$. putida

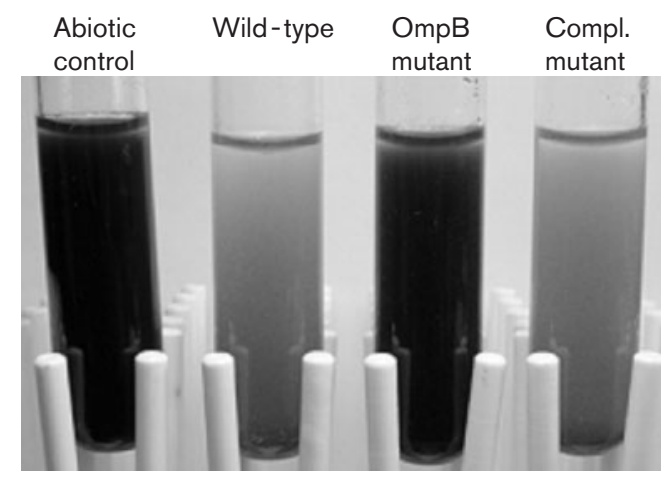

Fig. 5. Reduction of $\mathrm{Mn}(\mathrm{IV})$ by wild-type, ompB mutant and ompB mutant cells complemented with ompB in trans. The reduction of $\mathrm{Mn}(\mathrm{IV})$ is indicated by reduced intensity of colour. The pictures were taken after 20 days growth. 
(De Vrind et al., 2003). The genome of G. sulfurreducens contains the classical type II secretion system, showing more similarity to those in $V$. cholerae and $S$. putrefaciens (Sandkvist, 2001b), but its role in Fe(III) reduction has not been evaluated.

Another difference between the G. sulfurreducens and $S$. putrefaciens secretion systems required for $\mathrm{Fe}$ (III) reduction is that deleting ferE from $S$. putrefaciens inhibited the reduction of both soluble and insoluble $\mathrm{Fe}$ (III) (DiChristina et al., 2002), whereas deleting $\operatorname{oxp} G$ only inhibited Fe(III) oxide reduction in G. sulfurreducens. Preliminary evidence suggested that a haem-containing protein was not properly exported to the outer membrane in the secretion system mutant of $S$. putrefaciens, but the actual role of this cytochrome in $\mathrm{Fe}(\mathrm{III})$ reduction has yet to be determined (DiChristina et al., 2002). An outer-membrane c-type cytochrome, $\mathrm{OmcB}$, is also required for reduction of both soluble and insoluble $\mathrm{Fe}(\mathrm{III})$ in G. sulfurreducens (Leang et al., 2003). OmcB was not observed to accumulate in the periplasm of the $\exp G$ deletion mutant, and the fact that the $\operatorname{oxp} G$ deletion mutant could reduce soluble $\mathrm{Fe}$ (III) as well as the wild-type suggested that $\mathrm{OmcB}$ was properly positioned in the outer membrane. In contrast, the inhibition of $\mathrm{Fe}(\mathrm{III})$ and $\mathrm{Mn}$ (IV) oxide in the absence of a functioning secretion system in G. sulfurreducens could be attributed, at least in part, to the failure to export OmpB, which is not a $c$-type cytochrome.

\section{Role of OmpB in Fe(III) and Mn(IV) oxide reduction}

The results suggest that one reason why the oxpG-deficient mutant cannot reduce $\mathrm{Fe}(\mathrm{III})$ or $\mathrm{Mn}$ (IV) oxide is that OmpB is not exported across the outer membrane. Although previous studies on extracellular electron transport to $\mathrm{Fe}$ (III) and $\mathrm{Mn}$ (IV) oxides have primarily focused on the role of outer-membrane $c$-type cytochromes (Lovley et al., 2004; Richardson, 2000), it is becoming increasingly apparent that other types of proteins may also be important. For example, MtrB, which is a non-haem-containing outermembrane protein required for $\mathrm{Fe}(\mathrm{III})$ reduction in $S$. putrefaciens (Beliaev \& Saffarini, 1998), has the likely role of properly positioning cytochromes in the outer membrane (Myers \& Myers, 2002). Pilin is required for Fe(III) oxide reduction in G. sulfurreducens, with the probable role of facilitating the final step in electron transfer to $\mathrm{Fe}(\mathrm{III})$ oxides (Reguera et al., 2005).

The protein most closely related to OmpB is MofA of the $\mathrm{Mn}(\mathrm{II})$ and $\mathrm{Fe}(\mathrm{II})$-oxidizing micro-organism Leptothrix discophora (Brouwers et al., 2000a; Corstjens et al., 1997). Like MofA, OmpB contains four predicted copper-binding sites arranged in a manner commonly found in multicopper oxidases (Brouwers et al., 2000b). MofA is considered to be responsible for the oxidation of $\mathrm{Mn}(\mathrm{II})$. The partially purified MofA catalyses the oxidation of $\mathrm{Mn}$ (II) with oxygen as the electron acceptor (Corstjens et al., 1997). $\mathrm{Mn}(\mathrm{IV})$ is produced and accumulates in the sheath which surrounds the cells, where the putative manganese-oxidizing system is also found (Brouwers et al., 2000b). Mn(IV) oxide formation was also stimulated with the addition of copper to the medium, further suggesting the involvement of a copper protein.

Anaerobic functions for multicopper oxidases have not previously been proposed. It is not clear whether this protein is redox active, and what its substrates are. Further studies are needed to determine whether $\mathrm{OmpB}$ is directly involved in the reduction of $\mathrm{Fe}$ (III) oxide and $\mathrm{Mn}$ (IV), or whether it has a yet unknown function, which facilitates the reduction of these metals. The study of the amino acid sequence of $\mathrm{OmpB}$ reveals a unique feature of $\mathrm{OmpB}$ that is not found in other multicopper oxidases. It contains a fibronectin type III-like domain (see Supplementary Fig. S4), similar to those in bacterial hydrolases (Kataeva et al., 2002; Lin \& Xiong, 2004). The fibronectin domain occurs most frequently in cellulases and chitinases in bacteria (Lin \& Xiong, 2004; Watanabe et al., 1994). It is proposed that in those enzymes the fibronectin domain either facilitates the adhesion of the protein to polysaccharides or cell receptors, or it participates in the maintenance of the proper conformation at the binding and/or catalytic sites of the enzyme (Kataeva et al., 2002; Watanabe et al., 1994). OmpB also contains an EXXE motif, which may be a potential Fe-binding site. This motif was found to be responsible for $\mathrm{Fe}(\mathrm{III})$ binding in an $\mathrm{Fe}$ (III) transporter (FTR1) (see Supplementary Fig. S4) (Severance et al., 2004). A plausible explanation is that both the potential $\mathrm{Fe}(\mathrm{III})$-binding and fibronectin motifs of OmpB might be involved in association of the cell with $\mathrm{Fe}(\mathrm{III})$ oxide. Additional studies to further elucidate these properties and the possible redox activity of the copper are warranted.

\section{ACKNOWLEDGEMENTS}

This research was supported by the Office of Science (BER), US Department of Energy, Genomics:GTL program under cooperative agreement DE-FC02-02ER63446 and by the Office of Science (BER), US Department of Energy, grant no. DE-FG02-02ER63423.

\section{REFERENCES}

Anderson, R. T. \& Lovley, D. R. (2002). Microbial redox interactions with uranium: an environmental perspective. In Interactions of Microorganisms with Radionuclides, pp. 205-223. Edited by M. J. Keith-Roach \& F. R. Livens. Amsterdam: Elsevier.

Anderson, R. T., Vrionis, H. A., Ortiz-Bernad, I. \& 10 other authors (2003). Stimulating the in situ activity of Geobacter species to remove uranium from the groundwater of a uranium-contaminated aquifer. Appl Environ Microbiol 69, 5884-5891.

Arrieta, J. G., Sotolongo, M., Menendez, C., Alfonso, D., Trujillo, L. E., Soto, M., Ramirez, R. \& Hernandez, L. (2004). A type II protein secretory pathway required for levansucrase secretion by Gluconacetobacter diazotrophicus. J Bacteriol 186, 5031-5039.

Beliaev, A. S. \& Saffarini, D. A. (1998). Shewanella putrefaciens $m$ trB encodes an outer membrane protein required for $\mathrm{Fe}(\mathrm{III})$ and $\mathrm{Mn}$ (IV) reduction. J Bacteriol 180, 6292-6297. 
Brouwers, G. J., de Vrind, J. P., Corstjens, P. L., Cornelis, P., Baysse, C. \& de Vrind-de Jong, E. W. (1999). cumA, a gene encoding a multicopper oxidase, is involved in $\mathrm{Mn}^{2+}$ oxidation in Pseudomonas putida GB-1. Appl Environ Microbiol 65, 1762-1768.

Brouwers, G. J., Corstjens, P. L., de Vrind, J. P., Verkamman, A., de Kuyper, M. \& de Vrind-de Jong, E. W. (2000a). Stimulation of $\mathrm{Mn}^{2+}$ oxidation in Leptothrix discophora SS-1 by $\mathrm{Cu}^{2+}$ and sequence analysis of the region flanking the gene encoding putative multicopper oxidase MofA. Geomicrobiol J 17, 25-33.

Brouwers, G. J., Vijgenboom, E., Corstjens, P. L. A., de Vrind, M. J. P. M. \& de Vrind-de Jong, E. W. (2000b). Bacterial $\mathrm{Mn}^{2+}$ oxidizing systems and multicopper oxidases: an overview of mechanisms and functions. Geomicrobiol J 17, 1-24.

Caccavo, F., Jr, Lonergan, D. J., Lovley, D. R., Davis, M., Stolz, J. F. \& Mclnerney, M. J. (1994). Geobacter sulfurreducens sp. nov., a hydrogen- and acetate-oxidizing dissimilatory metal-reducing microorganism. Appl Environ Microbiol 60, 3752-3759.

Childers, S. E., Ciufo, S. \& Lovley, D. R. (2002). Geobacter metallireducens accesses insoluble Fe(III) oxide by chemotaxis. Nature 416, 767-769.

Coppi, M. V., Leang, C., Sandler, S. J. \& Lovley, D. R. (2001). Development of a genetic system for Geobacter sulfurreducens. Appl Environ Microbiol 67, 3180-3187.

Corstjens, P. L. A. M., DeVrind, J. P. M., Goosen, T. \& DeVrinddeJong, E. W. (1997). Identification and molecular analysis of the Leptothrix discophora SS-1 mofA gene, a gene putatively encoding a manganese-oxidizing protein with copper domains. Geomicrobiol $J$ 14, 91-108.

Dehio, M., Knorre, A., Lanz, C. \& Dehio, C. (1998). Construction of versatile high-level expression vectors for Bartonella henselae and the use of green fluorescent protein as a new expression marker. Gene 215, 223-229.

d'Enfert, C., Ryter, A. \& Pugsley, A. P. (1987). Cloning and expression in Escherichia coli of the Klebsiella pneumoniae genes for production, surface localization and secretion of the lipoprotein pullulanase. EMBO J 6, 3531-3538.

De Vrind, J., De Groot, A., Brouwers, G. J., Tommassen, J. \& De Vrind-De Jong, E. W. (2003). Identification of a novel Gsp-related pathway required for secretion of the manganese-oxidizing factor of Pseudomonas putida strain GB-1. Mol Microbiol 47, 993-1006.

DiChristina, T. J., Moore, C. M. \& Haller, C. A. (2002). Dissimilatory $\mathrm{Fe}(\mathrm{III})$ and $\mathrm{Mn}(\mathrm{IV})$ reduction by Shewanella putrefaciens requires $f e r E$, a homolog of the pulE ( $g s p E)$ type II protein secretion gene. J Bacteriol 184, 142-151.

Filloux, A. (1999). Type II protein secretion: the main terminal branch of the general secretory pathway. In Transport of Molecules Across Microbial Membranes, pp. 80-109. Edited by J. K. BroomeSmith, S. Baumberg, C. J. Stirling \& F. B. Ward. Cambridge: Cambridge University Press.

Finneran, K. T., Housewright, M. E. \& Lovley, D. R. (2002). Multiple influences of nitrate on uranium solubility during bioremediation of uranium-contaminated subsurface sediments. Environ Microbiol 4, 510-516.

Gharahdaghi, F., Weinberg, C. R., Meagher, D. A., Imai, B. S. \& Mische, S. M. (1999). Mass spectrometric identification of proteins from silver-stained polyacrylamide gel: a method for the removal of silver ions to enhance sensitivity. Electrophoresis 20, 601-605.

Hanahan, D. (1983). Studies on transformation of Escherichia coli with plasmids. J Mol Biol 166, 557-580.

Holmes, D. E., Finneran, K. T., O’Neil, R. A. \& Lovley, D. R. (2002). Enrichment of members of the family Geobacteraceae associated with stimulation of dissimilatory metal reduction in uranium-contaminated aquifer sediments. Appl Environ Microbiol 68, 2300-2306.

Kataeva, I. A., Seidel, R. D., 3rd, Shah, A., West, L. T., Li, X. L. \& Ljungdahl, L. G. (2002). The fibronectin type 3-like repeat from the Clostridium thermocellum cellobiohydrolase CbhA promotes hydrolysis of cellulose by modifying its surface. Appl Environ Microbiol 68, 4292-4300.

Kovach, M. E., Elzer, P. H., Hill, D. S., Robertson, G. T., Farris, M. A., Roop, R. M., 2nd \& Peterson, K. M. (1995). Four new derivatives of the broad-host-range cloning vector pBBR1MCS, carrying different antibiotic-resistance cassettes. Gene 166, 175-176.

Leang, C., Coppi, M. V. \& Lovley, D. R. (2003). OmcB, a c-type polyheme cytochrome, involved in $\mathrm{Fe}(\mathrm{III})$ reduction in Geobacter sulfurreducens. J Bacteriol 185, 2096-2103.

Lin, Y. \& Xiong, G. (2004). Molecular cloning and sequence analysis of the chitinase gene from Bacillus thuringiensis serovar alesti. Biotechnol Lett 26, 635-639.

Lloyd, J. R. \& Lovley, D. R. (2001). Microbial detoxification of metals and radionuclides. Curr Opin Biotechnol 12, 248-253.

Lloyd, J. R., Leang, C., Hodges Myerson, A. L., Coppi, M. V., Ciufo, S., Methe, B., Sandler, S. J. \& Lovley, D. R. (2003). Biochemical and genetic characterization of PpcA, a periplasmic $c$-type cytochrome in Geobacter sulfurreducens. Biochem J 369, 153-161.

Lovley, D. R. (1991). Dissimilatory $\mathrm{Fe}(\mathrm{III})$ and $\mathrm{Mn}(\mathrm{IV})$ reduction. Microbiol Rev 55, 259-287.

Lovley, D. R. (2000). Fe(III) and Mn(IV) reduction. In Environmental Microbe-Metal Interactions, pp. 3-30. Edited by D. R. Lovley. Washington, DC: American Society for Microbiology.

Lovley, D. R. \& Phillips, E. J. (1986). Organic matter mineralization with the reduction of ferric iron in anaerobic sediments. Appl Environ Microbiol 51, 683-689.

Lovley, D. R. \& Phillips, E. J. P. (1988). Novel mode of microbial energy metabolism: organic carbon oxidation coupled to dissimilatory reduction of iron or manganese. Appl Environ Microbiol 54, 1472-1480.

Lovley, D. R., Holmes, D. E. \& Nevin, K. P. (2004). Dissimilatory $\mathrm{Fe}(\mathrm{III})$ and $\mathrm{Mn}(\mathrm{IV})$ reduction. Adv Microb Physiol 49, 219-286.

Marx, C. J. \& Lidstrom, M. E. (2001). Development of improved versatile broad-host-range vectors for use in methylotrophs and other Gram-negative bacteria. Microbiology 147, 2065-2075.

Mehta, T., Coppi, M. V., Childers, S. E. \& Lovley, D. R. (2005). Outer membrane $c$-type cytochromes required for Fe(III) and $\mathrm{Mn}(\mathrm{IV})$ oxide reduction in Geobacter sulfurreducens. Appl Environ Microbiol 71, 8634-8641.

Methe, B. A., Nelson, K. E., Eisen, J. A. \& 8 other authors (2003). Genome of Geobacter sulfurreducens: metal reduction in subsurface environments. Science 302, 1967-1969.

Murphy, K. C., Campellone, K. G. \& Poteete, A. R. (2000). PCRmediated gene replacement in Escherichia coli. Gene 246, 321-330.

Myers, C. R. \& Myers, J. M. (2002). MtrB is required for proper incorporation of the cytochromes OmcA and OmcB into the outer membrane of Shewanella putrefaciens MR-1. Appl Environ Microbiol 68, 5585-5594.

Nakai, K. \& Horton, P. (1999). PSORT: a program for detecting sorting signals in proteins and predicting their subcellular localization. Trends Biochem Sci 24, 34-36.

Nevin, K. P. \& Lovley, D. R. (2000). Lack of production of electronshuttling compounds or solubilization of $\mathrm{Fe}(\mathrm{III})$ during reduction of insoluble Fe(III) oxide by Geobacter metallireducens. Appl Environ Microbiol 66, 2248-2251.

Nevin, K. P. \& Lovley, D. R. (2002). Mechanisms for Fe(III) oxide reduction in sedimentary environments. Geomicrobiol J 19, 141-159. 
Nevin, K. P., Finneran, K. T. \& Lovley, D. R. (2003). Microorganisms associated with uranium bioremediation in a high-salinity subsurface sediment. Appl Environ Microbiol 69, 3672-3675.

North, N. N., Dollhopf, S. L., Petrie, L., Istok, J. D., Balkwill, D. L. \& Kostka, J. E. (2004). Change in bacterial community structure during in situ biostimulation of subsurface sediment cocontaminated with uranium and nitrate. Appl Environ Microbiol 70, 4911-4920.

Nunn, D. (1999). Bacterial type II protein export and pilus biogenesis: more than just homologies? Trends Cell Biol 9, 402-408.

Ortiz-Bernad, I., Anderson, R. T., Vrionis, H. A. \& Lovley, D. R. (2004). Resistance of solid-phase $\mathrm{U}(\mathrm{VI})$ to microbial reduction during in situ bioremediation of uranium-contaminated groundwater. Appl Environ Microbiol 70, 7558-7560.

Pugsley, A. P. (1993a). The complete general secretory pathway in gram-negative bacteria. Microbiol Rev 57, 50-108.

Pugsley, A. P. (1993b). Processing and methylation of PuIG, a pilinlike component of the general secretory pathway of Klebsiella oxytoca. Mol Microbiol 9, 295-308.

Reguera, G., McCarthy, K. D., Mehta, T., Nicoll, J. S., Touminen, M. T. \& Lovley, D. R. (2005). Extracellular electron transfer via microbial nanowires. Nature 435, 1098-1101.

Richardson, D. J. (2000). Bacterial respiration: a flexible process for a changing environment. Microbiology 146, 551-571.

Röling, W. F., van Breukelen, B. M., Braster, M., Lin, B. \& van Verseveld, H. W. (2001). Relationships between microbial community structure and hydrochemistry in a landfill leachate-polluted aquifer. Appl Environ Microbiol 67, 4619-4629.

Rooney-Varga, J. N., Anderson, R. T., Fraga, J. L., Ringelberg, D. \& Lovley, D. R. (1999). Microbial communities associated with anaerobic benzene degradation in a petroleum-contaminated aquifer. Appl Environ Microbiol 65, 3056-3063.

Sambrook, J., Fritsch, J. E. \& Maniatis, T. (1989). Molecular Cloning: a Laboratory Manual, 2nd edn. Cold Spring Harbor, NY: Cold Spring Harbor Laboratory.

Sandkvist, M. (2001a). Biology of type II secretion. Mol Microbiol 40, 271-283.
Sandkvist, M. (2001b). Type II secretion and pathogenesis. Infect Immun 69, 3523-3535.

Sandler, S. J. \& Clark, A. J. (1994). RecOR suppression of recF mutant phenotypes in Escherichia coli K-12. J Bacteriol 176, 3661-3672.

Severance, S., Chakraborty, S. \& Kosman, D. J. (2004). The Ftrlp iron permease in the yeast plasma membrane: orientation, topology and structure-function relationships. Biochem J 380, 487-496.

Snoeyenbos-West, O. L., Nevin, K. P., Anderson, R. T. \& Lovley, D. R. (2000). Enrichment of Geobacter species in response to stimulation of $\mathrm{Fe}$ (III) reduction in sandy aquifer sediments. Microb Ecol 39, 153-167.

Stein, L. Y., La Duc, M. T., Grundl, T. J. \& Nealson, K. H. (2001). Bacterial and archaeal populations associated with freshwater ferromanganous micronodules and sediments. Environ Microbiol 3, 10-18.

Tor, J. M., Lovley, D. R., Kashefi, K. \& Holmes, D. E. (2004). Potential importance of dissimilatory $\mathrm{Fe}(\mathrm{III})$-reducing microorganisms in hot sedimentary environments. In The Subseafloor Biosphere at MidOcean Ridges, vol. 144, pp. 199-211. Edited by W. S. D. Wilcock, E. F. Delong, D. S. Kelley, J. A. Baross \& S. C. Cary. Washington, DC: American Geophysical Union.

Vargas, M., Kashefi, K., Blunt-Harris, E. L. \& Lovley, D. R. (1998). Microbiological evidence for Fe(III) reduction on early Earth. Nature 395, 65-67.

Vignon, G., Kohler, R., Larquet, E., Giroux, S., Prevost, M. C., Roux, P. \& Pugsley, A. P. (2003). Type IV-like pili formed by the type II secreton: specificity, composition, bundling, polar localization, and surface presentation of peptides. J Bacteriol 185, 3416-3428.

Walker, J. C. G. (1987). Was the Archaean biosphere upside down? Nature 329, 710-712.

Watanabe, T., Ito, Y., Yamada, T., Hashimoto, M., Sekine, S. \& Tanaka, H. (1994). The roles of the C-terminal domain and type III domains of chitinase A1 from Bacillus circulans WL-12 in chitin degradation. J Bacteriol 176, 4465-4472.

Woodcock, D. M., Crowther, P. J., Doherty, J., Jefferson, S., DeCruz, E., Noyer-Wiedner, M., Smith, S. S., Michael, M. Z. \& Graham, M. W. (1989). Quantitative evaluation of Escherichia coli host strains for tolerance to cytosine methylation in plasmid and phage recombinants. Nucleic Acids Res 17, 3469-3478. 